\title{
Production Potential and Economics of Bt. Cotton based Intercropping System under Rainfed Condition
}

\author{
D. S. Hirpara, V. D. Vora* , P. D. Vekaria, K. S. Jotangiya, \\ H. R. Vadar, V. L. Modhavadiya and T. J. Patel
}

Dry Farming Research Station, Junagadh Agricultural University, Targhadia (Gujarat), India

*Corresponding author

\section{A B S T R A C T}

\begin{tabular}{l} 
K e y w o r d s \\
$\begin{array}{l}\text { Bt. Cotton, } \\
\text { Intercropping, } \\
\text { Alternate land use } \\
\text { system, MCEY }\end{array}$ \\
\hline Article Info \\
$\begin{array}{l}\text { Accepted: } \\
\text { 24 October } 2020 \\
\text { Available Online: } \\
\text { 10 November } 2020\end{array}$ \\
\hline
\end{tabular}

\section{Introduction}

Cotton (Gossypium sp.) is one of the most important fibre and cash crop in India belongs to Malvaceae family and known as "King of Fiber" and "White gold" plays a prominent role in the rural, national and international economy. It is grown mostly for fibre used in the manufacture of cloths for mankind. In recent years, cotton apparels are being preferred to the synthetic ones due to the increasing the health consciousness among the people. Besides fibre, cotton is also valued for its oil (15 - 20\%) which are used as
A field experiment was conducted on medium black soil to study the production potential and economics of Bt. cotton based intercropping system under rain fed condition at Dry Farming Research Station, Junagadh Agricultural University, Targhadia, Gujarat during kharif- 2015-16 to 2018-19. The experiment comprising of eight treatments with four replications laid out in randomized block design. In pooled results, the treatment inter cropping of cotton + cowpea $\left(\mathrm{T}_{8}\right)$ produced significantly higher MCEY $(2815 \mathrm{~kg} / \mathrm{ha})$, which was statistically at par with treatment $\mathrm{T}_{6}$ (cotton + sesame), $\mathrm{T}_{3}$ (cotton + green gram), $\mathrm{T}_{4}$ (cotton + black gram) and $\mathrm{T}_{2}$ (cotton + groundnut).Among the intercrops, maximum main product yield $(1074 \mathrm{~kg} / \mathrm{ha})$ was recorded with treatment $\mathrm{T}_{5}$ (cotton + gum guar) followed by cotton + soybean $(896 \mathrm{~kg} / \mathrm{ha})$ and cotton + groundnut $(884 \mathrm{~kg} / \mathrm{ha})$, whereas $\mathrm{T}_{3}$ (cotton + green gram) produced minimum seed yield $(388 \mathrm{~kg} / \mathrm{ha})$ with cotton . Among the intercrops, gum guar recorded maximum by product yield $2609 \mathrm{~kg} / \mathrm{ha}$ followed by groundnut haulm yield $2534 \mathrm{~kg} / \mathrm{ha}$ and minimum by product yield $608 \mathrm{~kg} / \mathrm{ha}$ recorded by green gram as intercrop with cotton. 
growth duration for enabling the utilization of natural resources optimally (Sankaranarayanan et al., 2012). Intercropping has been recognized as potentially beneficial and economic system of crop production. Similarly intercropping is one of the ways to increase the cropping intensity and resource utilization (Harisudan et al., 2008). Usually a yield advance occurs as component crop differ in their use of resources when they are grown in combination, they are able to component each other and make better use of resources. Due to slow growing nature of cotton much of the vacant interspaces remains utilized during initial stages of the crop growth. This situation offers ample scope for raising intercrops (Nehra et al., 1990). Intercropping provides the insurance against the inclement weather situation and consequent crops (Balasubramanian, 1987) observed increase in productivity with higher market value and enhanced profitability, when pulses were intercropped with cotton. Intercropping of legumes is an important aspect for biological farming system not only for weed control, but also in reducing the leaching of nutrients, pest control and in reducing soil erosion (Prabukumar and Uthayakumar, 2006). Keeping all these views in mind an experiment was conducted to find out the effect of different intercrops on growth and yield attributes on Bt. cotton under rain fed condition.

\section{Materials and Methods}

The experiment was conducted on medium black soil of dry farming research station, of Junagadh Agricultural University, Targhadia (Gujarat) during four consecutive kharif seasons of 2015-16to 2018-19. The year wise total rainfall received during the crop growth seasons 2015 to 2018 were 604.4, 425.1, 1328.5 and $613.6 \mathrm{~mm}$, with 26, 27, 38and 26 rainy days, respectively. The soil of the experimental field was medium black having good drainage and high moisture retentive capacity. Some important characteristics of the soil were $\mathrm{pH} 8.30$, EC $0.35 \mathrm{dS} / \mathrm{m}$, Organic carbon $0.41 \%$, available $\mathrm{N}, \mathrm{P}, \mathrm{K}$ and $\mathrm{S}$ were $230.3,28.6$, and $336 \mathrm{~kg} / \mathrm{ha}$ and $17.8 \mathrm{ppm}$, respectivelyand micronutrient $\mathrm{Fe}, \mathrm{Mn}$ and $\mathrm{Zn}$ were $10.19,12.84$ and $0.66 \mathrm{ppm}$, respectively. The experiment comprises eight treatments. $\mathrm{T}_{1}$ - sole cotton crop, $\mathrm{T}_{2}$-cotton + Groundnut, $\mathrm{T}_{3}$-Cotton + Greengram, $\mathrm{T}_{4}$-Cotton + Blackgram, $\mathrm{T}_{5}$-Cotton + Gum guar, $\mathrm{T}_{6^{-}}$ Cotton + Sesame, $\mathrm{T}_{7}$-Cotton + Soybean and $\mathrm{T}_{8}$-Cotton+ Cowpea. The cotton variety $\mathrm{B}$-II Hybrid-8, and all other crops variety likewise Groundnut variety GG-5, Green gram variety GM-4, Black gram variety Guj. BG-1, Gum Guar variety Guj.Guar-1, Sesame variety Gujarat Til-2, Soybean variety JS-335 and Cow pea variety Gujarat Cow pea-4 were sown.

The experiment was laid out in randomized block design with four replications and individual plot size of $6.0 \mathrm{~m} \times 4.8 \mathrm{~m}$ (gross) and $5.0 \mathrm{~m} \times 2.4 \mathrm{~m}$ (net). Cotton seeds of cv.Bt. Cot. Hybrid-8was sown at $120 \mathrm{~cm}$ row to row and $30 \mathrm{~cm}$ plant to plant distance and all other intercrops were sown at $120 \mathrm{~cm}$ row to row and $10 \mathrm{~cm}$ (Groundnut, Green gram, Black gram, Gum Guar, Sesame, Soybean, Cowpea) plant to plant distance with bullock drawn seed drill. The crops were fertilized with irrespective of RDF NPK kg/ha. All other recommended agricultural practices were followed throughout crop period. Main product yield and by product yield were recorded at the time of crop harvest. Economics of all the treatments was worked out. The Seed cotton equivalent yield and B:C ratio were calculated by using following formula.

Seed cotton equivalent yield $=\frac{\text { Yield of crop 'B' } x \text { Unit price of produce 'B' }(\mathrm{Rs} / \mathrm{q})}{\text { Unit price of 'A'(Rs. } / \mathrm{q})}$ 
B:C ratio $=\frac{\text { Gross monetary retums }(\mathrm{Rs} / \mathrm{ha})}{\text { Cost of cultivation }(\mathrm{Rs} / \mathrm{ha})}$

\section{Results and Discussion}

\section{Seed cotton equivalent yield}

The data presented in table 1 revealed that Seed cotton equivalent yield was significantly affected due to different treatments in all the years of experimentation and in pooled results also. The Seed cotton equivalent yield i.e. Main Crop (seed cotton) Equivalent Yield (MCEY) was worked out considering year wise current selling rate of main produce in marketing yard.

The results revealed that during year 2015-16 treatment $\mathrm{T}_{8}$ (Cotton + Cowpea) produced significantly the highest MCEY (3360 kg/ha), while during year 2016-17, treatment $\mathrm{T}_{3}$ (cotton + green gram) produced significantly higher MCEY (2064 kg/ha), which remained statistically at par with intercropping of sesame, black gram, cowpea and groundnut with cotton.

During year 2017-18, treatment $\mathrm{T}_{6}$ (cotton + sesame) produced significantly higher MCEY (2967 kg/ha), which remained statistically at par with $\mathrm{T}_{8}$ (Cotton + Cowpea), similarly during 2018-19, treatment $\mathrm{T}_{6}$ (cotton + sesame) produced significantly higher MCEY (3348 kg/ha), which remained statistically at par with intercropping of cowpea, groundnut and black gram with cotton.

In pooled results $\mathrm{T}_{8}$ (cotton + cowpea) produced significantly higher MCEY (2815 $\mathrm{kg} / \mathrm{ha}$ ), which was statistically at par with treatments $\mathrm{T}_{6}$ (cotton + sesame), $\mathrm{T}_{3}$ (cotton + green gram), $\mathrm{T}_{4}$ (cotton + black gram) and $\mathrm{T}_{2}$ (cotton + groundnut). These results are in agreement with the findings of Ramachandrappa et al., (2016) and Manoj et al., (2013).

\section{Main product (Pod/ Seed/ Grain) yield}

The data presented in table 2 revealed that among various treatments average maximum (2015-16 to 2018-19) seed cotton yield (2124 $\mathrm{kg} / \mathrm{ha}$ ) was recorded in treatment $\mathrm{T}_{3}$ (cotton + green gram) followed by sole cotton (2114 $\mathrm{kg} / \mathrm{ha})$, cotton + green gram $(2060 \mathrm{~kg} / \mathrm{ha})$ and cotton+ cowpea $(2047 \mathrm{~kg} / \mathrm{ha})$, whereas minimum seed cotton yield $(1269 \mathrm{~kg} / \mathrm{ha})$ was recorded in treatment $\mathrm{T}_{5}$ (cotton + gum guar).

Among the intercrop, average maximum main product yield $(1074 \mathrm{~kg} / \mathrm{ha})$ was recorded with treatment $\mathrm{T}_{5}$ (cotton + gum guar) followed by cotton + soybean $(896 \mathrm{~kg} / \mathrm{ha})$ and cotton + groundnut $(884 \mathrm{~kg} / \mathrm{ha})$, whereas $\mathrm{T}_{3}$ (cotton + green gram) crop produced minimum seed yield (388 kg/ha) with cotton as base crop.

\section{By product (Haulm/Fodder/Stalk) yield}

The results presented in table 3 revealed that in average of four years, cotton as base crop produced maximum by product yield (3997 $\mathrm{kg} / \mathrm{ha}$ ) under treatment $\mathrm{T}_{3}$ (cotton + green gram) followed by $3936 \mathrm{~kg} / \mathrm{ha}$ as sole cotton $\left(\mathrm{T}_{1}\right)$ and 3717 with black gram $\left(\mathrm{T}_{4}\right)$ as inter crop while minimum by product yield 2909 $\mathrm{kg} / \mathrm{ha}$ of cotton recorded under treatment $\mathrm{T}_{5}$ (cotton + gum guar).

In case of different intercrops, maximum average by product yield $2609 \mathrm{~kg} / \mathrm{h}$ are corded under gum guar followed by 2534 $\mathrm{kg} / \mathrm{ha}$ under groundnut haulm the useful fodder of cattle and minimum average by product $608 \mathrm{~kg} / \mathrm{ha}$ recorded under green gram sown as intercrop with cotton.

Results clearly indicates that by product yield potentiality of cotton in sole as well as intercrop system showing exhaustiveness of cotton as base crop in dry farming region. 
Table.1 Effect of treatments on seed cotton equivalent yield (MCEY)

\begin{tabular}{|c|c|c|c|c|c|}
\hline Treatment & $2015-16$ & $2016-17$ & $2017-18$ & $2018-19$ & Pooled \\
\hline$T_{1}-$ Sole cotton & 2437 & 1591 & 1998 & 2431 & 2114 \\
\hline$T_{2^{-}}$Cotton + groundnut $(1: 1)$ & 2223 & 1880 & 2539 & 3141 & 2446 \\
\hline$T_{3^{-}}$Cotton + green gram $(1: 1)$ & 2738 & 2064 & 2537 & 2693 & 2508 \\
\hline$T_{4^{-}}$Cotton + black gram $(1: 1)$ & 2505 & 2001 & 2409 & 2939 & 2464 \\
\hline$T_{5^{-}}$Cotton + gum guar $(1: 1)$ & 2082 & 1359 & 2206 & 2452 & 2025 \\
\hline$T_{6^{-}}$Cotton + sesame $(1: 1)$ & 2287 & 2049 & 2967 & 3448 & 2688 \\
\hline$T_{7^{-}}$Cotton + soybean $(1: 1)$ & 1917 & 1664 & 2143 & 2154 & 1970 \\
\hline$T_{8^{-}}$Cotton + cowpea $(1: 1)$ & 3360 & 1928 & 2656 & 3317 & 2815 \\
\hline S.Em. \pm & 126 & 122 & 143 & 176 & 126 \\
\hline C.D. at $5 \overline{\%}$ & 371 & 358 & 419 & 517 & 371 \\
\hline \multirow[t]{2}{*}{ C.V.\% } & 10.3 & 13.4 & 11.7 & 12.5 & 12 \\
\hline & $\mathbf{Y}$ & YXT & & & \\
\hline S.Em. \pm & 89 & 143 & & & \\
\hline C.D. at $5 \%$ & 262 & 403 & & & \\
\hline
\end{tabular}

Table.2 Effect of various treatments on seed/pod/grain/seed cotton yields (kg/ha)

\begin{tabular}{|c|c|c|c|c|c|c|c|c|c|c|}
\hline \multirow[t]{3}{*}{ Treatment } & \multicolumn{2}{|c|}{$2015-2016$} & \multicolumn{2}{|c|}{$2016-2017$} & \multicolumn{2}{|c|}{$2017-2018$} & \multicolumn{2}{|c|}{$2018-2019$} & \multicolumn{2}{|c|}{ Average } \\
\hline & \multicolumn{10}{|c|}{ Main Product yield(kg/ha) } \\
\hline & cotton & IC & cotton & IC & cotton & IC & cotton & IC & cotton & IC \\
\hline $\mathbf{T}_{1}$ & 2437 & - & 1591 & - & 1998 & - & 2431 & & 2114 & \\
\hline $\mathbf{T}_{2}$ & 1612 & 645 & 1338 & 709 & 2053 & 608 & 1852 & 1572 & 1714 & 884 \\
\hline $\mathbf{T}_{3}$ & 2322 & 291 & 1862 & 317 & 2041 & 520 & 2269 & 424 & 2124 & 388 \\
\hline $\mathbf{T}_{4}$ & 2088 & 271 & 1862 & 163 & 2066 & 456 & 2222 & 872 & 2060 & 441 \\
\hline $\mathbf{T}_{5}$ & 1589 & 586 & 791 & 1043 & 890 & 1778 & 1806 & 889 & 1269 & 1074 \\
\hline$T_{6}$ & 1734 & 375 & 1411 & 585 & 2032 & 583 & 1736 & 818 & 1728 & 590 \\
\hline $\mathbf{T}_{7}$ & 1480 & 549 & 1107 & 1020 & 1688 & 839 & 1458 & 1176 & 1433 & 896 \\
\hline $\mathbf{T}_{8}$ & 2138 & 968 & 1575 & 431 & 1951 & 741 & 2523 & 723 & 2047 & 716 \\
\hline
\end{tabular}

Table.3 Effect of various treatments on fodder/stalk/haulm yields $(\mathrm{kg} / \mathrm{ha})$

\begin{tabular}{|c|c|c|c|c|c|c|c|c|c|c|}
\hline \multirow{3}{*}{$\begin{array}{c}\text { Treatmen } \\
\mathbf{t}\end{array}$} & \multicolumn{2}{|c|}{$2015-2016$} & \multicolumn{2}{|c|}{$2016-2017$} & \multicolumn{2}{|c|}{$2017-2018$} & \multicolumn{2}{|c|}{$2018-2019$} & \multicolumn{2}{|c|}{ Average } \\
\hline & \multicolumn{10}{|c|}{ By Product yield (kg/ha) } \\
\hline & cotton & IC & cotton & IC & cotton & IC & cotton & IC & cotton & IC \\
\hline $\mathbf{T}_{1}$ & 3689 & - & 3574 & - & 4204 & - & 4278 & & 3936 & \\
\hline $\mathbf{T}_{2}$ & 2474 & 1931 & 3278 & 2870 & 4407 & 2574 & 3093 & 2759 & 3313 & 2534 \\
\hline$T_{3}$ & 3451 & 265 & 3944 & 1361 & 4667 & 491 & 3926 & 315 & 3997 & 608 \\
\hline $\mathbf{T}_{4}$ & 3016 & 380 & 3685 & 333 & 4370 & 602 & 3796 & 1303 & 3717 & 654 \\
\hline$T_{5}$ & 2431 & 2517 & 2352 & 3111 & 3278 & 2685 & 3574 & 2122 & 2909 & 2609 \\
\hline $\mathbf{T}_{6}$ & 2865 & 1172 & 3185 & 1148 & 5000 & 1204 & 3259 & 1426 & 3577 & 1237 \\
\hline $\mathbf{T}_{7}$ & 2452 & 1128 & 3056 & 1419 & 4296 & 2370 & 3111 & 2278 & 3229 & 1799 \\
\hline $\mathbf{T}_{8}$ & 2865 & 321 & 3222 & 1500 & 4222 & 519 & 4000 & 500 & 3577 & 710 \\
\hline
\end{tabular}


Table.4 Economics of different treatments

\begin{tabular}{|c|c|c|c|c|c|c|c|}
\hline Treatment & MCEY & \multicolumn{2}{|c|}{ Byproduct yield } & $\begin{array}{c}\text { Cost of } \\
\text { cultivation } \\
\text { (Rs/ha) }\end{array}$ & $\begin{array}{c}\text { Gross } \\
\text { Return } \\
\text { (Rs./ha) }\end{array}$ & $\begin{array}{c}\text { Net } \\
\text { return } \\
\text { (Rs/ha) }\end{array}$ & $\begin{array}{c}\text { B:C } \\
\text { ratio }\end{array}$ \\
\hline T1 & 2114 & 3936 & - & 33065 & 118238 & 85173 & 3.58 \\
\hline T2 & 2446 & 3313 & 2534 & 35953 & 148857 & 112904 & 4.14 \\
\hline T3 & 2508 & 3997 & 608 & 34747 & 140547 & 105800 & 4.04 \\
\hline T4 & 2464 & 3717 & 654 & 34903 & 138033 & 103130 & 3.95 \\
\hline T5 & 2025 & 2909 & 2609 & 34104 & 115439 & 81335 & 3.38 \\
\hline T6 & 2688 & 3577 & 1237 & 34009 & 150247 & 116238 & 4.42 \\
\hline T7 & 1970 & 3229 & 1799 & 35210 & 111764 & 76554 & 3.17 \\
\hline T8 & 2815 & 3577 & 710 & 34760 & 157324 & 122564 & 4.53 \\
\hline
\end{tabular}

\section{Economics}

Economic response of sole cotton and cotton with intercrop was worked out on the basis of pooled result and presented in table 4 . The data indicated that treatment $\mathrm{T}_{8}$ (cotton + cowpea in between two rows of cotton) gave maximum net return of Rs. 122564 with B:C ratio (4.53) followed by cotton + sesame (4.42), cotton + groundnut (4.14) and cotton + green gram (4.04).Pulses intercropped with cotton were also noticed by Maitraet al. (2001) to give higher returns.

In conclusion under North Saurashtra Agro Climatic Zone (AES-VI) in cotton based intercrop system under rainfed condition growing cowpea in between two rows of cotton produce higher yield and net return followed by intercropping of sesame or groundnut or green gram in between two rows of cotton as next better optional crops.

\section{References}

Anonymous, (2018).The Cotton Corporation of India Ltd., http://www.cotcorp. gov.in/statistics.aspx accessed on 17 October 2019.

Balasubramanian, T.N. (1987). Performance of arboreum and hirsutum cotton under intercropping (Blackgram) and land management practices. Ph.D. thesis, Tamil Nadu Agriculture University, Coimbatore, India.

Harisudan, C., Senthivel, S., Arulmozhiselvan, K., Vaidyanathan, R., and Manivannan, V. (2008). International Journal of Tropical Agriculture, 26(3-4): 311-313.

Maitra, S.S.K., Samui., Roy, D.K., and Mondal, A.K. (2001). Effect of cotton based intercropping system under rainfed conditions in Sunderban region of West Bengal. Indian Agriculturist, 45: 157-62.

Manoj, K., Shivran, A. C., Rekha, C., Meena, K. S., Verma, K. C., Jat, R. D and Balai, L.P. (2013). Production potential and economics of intercropping of castor with mungbean. Environment and Ecology. 31(2C) pp.1065-1068.

Nehra, D.S. (1990). Journal of Cotton Research and Development.,4(1): 128129.

Prabukumar, G. and Uthayakumar, B. (2006). Use of organics for crops for crop production under rainfed situation, Agriculture Rev, 27(3): 208-215.

Ramachandrappa, B. K., Thimmegowda, M. N., Sathish, A., Dhanapal, G. N. and Ravi Kumar, H. S. (2016). Effect of intercropping in nipped castor (Ricinus 
communis L.) under rainfed conditions. Indian Journal of Dryland Agriculture Research\& Development, 31(1): 30-36.

Sankaranarayanan, K., Nalayini, P., and Praharaj, C.S. (2012). Multi-tier cropping system to enhance resource utilization, profitability and sustainability of Bt cotton (Gossypium hirsutum) production system. Indian Journal of Agricultural Science, 82(12): 1044-50.

\section{How to cite this article:}

Hirpara, D. S., V. D. Vora, P. D. Vekaria, K. S. Jotangiya, H. R. Vadar, V. L. Modhavadiya and Patel, T. J. 2020. Production Potential and Economics of Bt. Cotton based Intercropping System under Rainfed Condition. Int.J.Curr.Microbiol.App.Sci. 9(11): 3385-3390.

doi: https://doi.org/10.20546/ijcmas.2020.911.404 